\title{
ANALISIS KINERJA KARYAWAN DIVISI MILL DAN BOILER PT GULA PUTIH MATARAM
}

\author{
Employee Performance Analysis of Mill and Boiler Division \\ in PT. Gula Putih Mataram
}

\author{
Sudibyo ${ }^{1)}$, Slamet Hartono ${ }^{2)}$, Azwar Maas $^{2)}$ \\ ${ }^{1)}$ Pascasarjana Ekonomi Pertanian Fakultas Pertanian Universitas Gadjah Mada \\ 2) Fakultas Pertanian Universitas Gadjah Mada
}

\begin{abstract}
The objectives of this study are to analyze the understanding of employee of Mill and Boiler Division, PT Gula Putih Mataram to employee performance factors and their impact on employee performance. Fifty two employees of Mill and Boiler Division are drawn purposively as the respondents. The data of employee understanding on job description, SOP, employee relation, KPI, technical aspect, and employee performance were collected frm the respondent through interview using prepared questionnaire. Data of employee performance was collected from the office of PT GPM. The result of data analysis shows that the performance of chief, officer, and supervisor in Mill and Boiler Division is good at rate of 70-80 percent. Factors affecting employee performance are understandings of employee on job description and SOP and employee relation. The study suggests to improve understanding of employee on job description and SOP and employee relation.
\end{abstract}

\section{PENDAHULUAN}

Tanaman tebu (Saccharum officinarum L) merupakan tanaman perkebunan semusim, yang di dalam batangnya terdapat zat gula. Tanaman tebu dapat dipanen pada umur 10-12 bulan, yaitu pada fase kemasakan (Supriyadi,1992). Tebu yang telah ditebang di kebun diangkut ke pabrik. Setelah sampai di halaman pabrik (cane yard), sebagian tebu langsung dibongkar di meja pengisian tebu dan sebagian tebu dibongkar dan dipindahkan untuk diumpankan ke mesin penggilingan dengan sistim FIFO. Kecepatan pemindahan diatur sedemikian rupa sesuai dengan kapasitas giling pabrik.

Proses selanjutnya adalah di cane preparation yaitu proses pencacahan tebu di unit cane cutter dan selanjutnya dicabik di cane shredder sehingga tebu menjadi sabut. Setelah itu dilakukan proses pemerahan nira (air tebu yang mengandung zat gula/pol). Hasil pemerahan nira tergantung pada hasil perusakan jaringan batang tebu di bagian gilingan. Pemerahan akan berhasil baik jika jaringan tebu benar-benar tersayat-sayat dan sel-sel tempat penyimpanan nira tebu menjadi terbuka.
Nira yang diperoleh dari proses pemerahan ini selanjutnya mengalami proses pemisahan sukrosa dan dikristalkan di bagian pengolahan. Produksi gula dipengaruhi oleh banyaknya pol yang dapat diperah. Pemerahan pol dapat menjadi salah satu penentu penting dalam produksi gula. Parameter ampas tebu sisa dari hasil proses pemerahan di mill yang harus dipantau adalah pol, karena semakin besar pol dalam ampas tebu maka semakin besar kehilangan gula dan selanjutnya semakin berkurang produksi gula.

Divisi mill dan boiler bertugas menggiling tebu, dan memerah nira yang diperlukan oleh divisi proses untuk selanjutnya diolah dan dikristalkan menjadi gula. Target perusahaan dalam pemerahan tebu adalah pol dalam ampas buangan hasil proses pemerahan di bawah $1,2 \%$. Besarnya hasil pemerahan pol dalam tebu dipengaruhi beberapa faktor dan yang paling menentukan adalah faktor manusia.

Penelitian ini bertujuan untuk mengetahui (i) pemahaman karyawan Divisi Mill dan Boiler PT GPM terhadap faktor-faktor yang mempengaruhi kinerja dan (ii) kinerja karyawan Divisi Mill dan Boiler PT Gula Putih Mataram (PT GPM) serta faktor-faktor yang mempengaruhinya. 


\section{METODE PENELITIAN}

\section{Kerangka Teori}

Pemahaman karyawan terhadap faktorfaktor yang mempengaruhi kinerja yaitu Standard Operating Procedure (SOP), hubungan kerja karyawan, Key Performance Indicator (KPI), dan aspek teknis pekerjaan serta pemahaman karyawan terhadap pengertian kinerja itu sendiri berpengaruh terhadap kinerja karyawan Divisi Mill dan Boiler PT GPM.

SOP adalah pedoman yang berisi prosedurprosedur operasional stamdard yang ada dalam suatu organisasi yang digunakan untuk memastikan bahwa setiap keputusan, langkah dan tindakan dan penggunaan fasilitas pemrosesan yang dilaksanaan oleh orang-orang di dalam suatu organisasi telah berjalan secara efektif, konsisten, standard, dan sistematis (Hadiwiyono dan Panjaitan, 2013).

KPI adalah ukuran yang akan dipergunakan untuk menilai kemajuan kinerja perusahaan disusun dengan menyesuaikan kondisi perusahaan. KPI sebagai indikator yang memberikan informasi kemajuan perusahaan disusun berdasarkan tujuan bisnis yang hendak dicapai perusahaan melalui pemenuhan kepuasan stakeholder. Tahap penyusunan KPI meliputi tahap pengidentifikasian KPI, tahap validasi KPI, dan tahap spesifikasi KPI Penentuan (Amilia, 2013).

Wijanto dan Sutanto (2013) menyimpulkan bahwa (i) hubungan atasan dan bawahan berpengaruh terhadap motivasi kerja, kepuasan kerja, komitmen organisasional, (ii) hubungan atasan dan bawahan berpengaruh terhadap komitmen organisasional melalui motivasi kerja, (iii) hubungan atasan dan bawahan berpengaruh terhadap komitmen organisasional melalui kepuasan kerja, dan (iv) hubungan atasan dan bawahan berpengaruh terhadap komitmen organisasional melalui kepuasan kerja dan motivasi kerja.

Kinerja adalah hasil kerja yang dapat dicapai oleh seseorang atau sekelompok orang dalam suatu organisasi sesuai dengan wewenang dan tanggungjawab masing-masing, dalam rangka upaya mencapai tujuan organisai bersangkutan secara legal, tidak melanggar hukum dan sesuai dengan moral dan etika (Prawirosentono, 1999).
Kinerja karyawan merefleksikan bagaimana karyawan memenuhi keperluan pekerjaan dengan baik (Werther et. al. (1996) Kinerja pada dasarnya adalah apa yang dilakukan dan tidak dilakukan karyawan. Kinerja karyawan dapat diukur dari seberapa banyak karyawan memberikan kontribusi kepada organisasi yang antara lain termasuk: (a) kuantitas keluaran, (b) kualitas keluaran, (c) jangka waktu keluaran, (d) kehadiran di tempat kerja, dan (e) sikap kooperatif (Mathis dan Jackson, 2002).

$\begin{array}{ccr}\text { Kinerja } & \text { perorangan } & \text { (individual } \\ \text { performance) } & \text { dengan kinerja } & \text { lembaga } \\ \text { (institutional } & \text { performance) atau kinerja }\end{array}$ perusahaan (corporate performance) terdapat hubungan yang erat. Bila kinerja karyawan baik maka kemungkinan besar kinerja perusahaan juga baik. Kinerja seorang karyawan akan baik bila karyawan tersebut mempunyai keahlian (skill) yang tinggi, bersedia bekerja karena gaji atau diberi upah sesuai dengan perjanjian, dan mempunyai harapan (expectation) masa depan yang lebih baik (Prawirosentono, 1999).

Manajemen kinerja (performance management) adalah suatu upaya untuk memperoleh hasil terbaik dari organisasi, kelompok dan individu melalui pemahaman dan penjelasan kinerja dalam suatu kerangka kerja atas tujuan-tujuan terencana, standar dan persyaratan-persyaratan atribut atau kompetensi yang disetujui bersama (Armstrong, 1998).

Manajemen kinerja bersifat menyeluruh dan menjamah semua elemen, unsur atau input yang harus didayagunakan oleh organisasi untuk meningkatkan kinerja organisasi. Menurut Mathis dan Jackson (2002), sistem manajemen kinerja berusaha mengidentifikasikan, mendorong, mengukur, mengevaluasi, meningkatkan dan memberi penghargaan terhadap kinerja karyawan.

Bacal (2001) mengemukakan bahwa manajemen kinerja meliputi upaya membangun harapan yang jelas serta pemahaman tentang unsur-unsur: (a) fungsi kerja esensial yang diharapkan dari para karyawan, (b) seberapa besar kontribusi pekerjaan karyawan bagi pencapaian tujuan organisasi, (c) apa arti konkretnya melakukan pekerjaan yang baik, (d) bagaimana karyawan dan penyedianya bekerja 
sama untuk mempertahankan, memperbaiki, maupun mengembangkan kinerja karyawan yang sudah ada sekarang, (e) bagaimana prestasi kerja akan diukur, dan (f) mengenali berbagai hambatan kinerja dan menyingkirkannya.

\section{Data}

Data dalam penelitian ini meliputi data primer yaitu data yang dikumpulkan dari karyawan Divisi Mill dan Boiler dan data sekunder yaitu data yang telah tersedia di PT GPM. Data primer dikumpulkan dari 52 karyawan Divisi Mill dan Boiler PT GPM yang dipilih secara purposif, meliputi identitas responden (umur, pendidikan, pengalaman pelatihan, posisi, diskripsi pekerjaan, dsb.), pemahaman responden terhadap SOP, hubungan kerja, KPI, aspek teknis, dan kinerja. Pengukuran pemahaman responden terhadap faktor-faktor tersebut dilakukan dengan Skala Likert. Data sekunder terutama kinerja karyawan adalah KPI yang dicapai oleh responden dalam bulan Oktober dan Nopember 2013.

Validitas dan reabilitas kuesioner yang digunakan untuk mengumpulkan data primer diuji dengan uji validitas dan uji reliabilitas. Kinerja karyawan diukur dengan capaian KPI yang ditetapkan perusahan, diukur dengan persentase hari tercapainya KPI dalam sebulan. KPI karyawan tercantum pada Tabel 1.

Pemahaman karyawan terhadap faktorfaktor yang mempengaruhi kinerja (SOP, Kinerja, Hubungan Kerja, KPI, Aspek Tekinis) diukur dengan Skala Likert seperti pada tabel 2.

Tabel 1. KPI untuk karyawan Cane dan boiller

\begin{tabular}{|c|c|c|c|}
\hline $\begin{array}{c}\text { Chief dan Officer Mill } \\
\text { dan Bolier }\end{array}$ & Mill Supervisor & $\begin{array}{c}\text { Mill Mechanic } \\
\text { Supervisor }\end{array}$ & $\begin{array}{c}\text { Cane Handling } \\
\text { Supervisor }\end{array}$ \\
\hline Pol Baggasse $(<1,2)$ & $\begin{array}{c}\text { Imbibisi \% fiber } \\
(>220 \%)\end{array}$ & $\begin{array}{c}\text { Kondisi equipment di } \\
\text { mill (siap operasional) }\end{array}$ & $\begin{array}{c}\text { Mengatur cane yard } \\
\text { (FIFO) }\end{array}$ \\
\hline $\begin{array}{c}\text { Moisture Baggasse } \\
(<47)\end{array}$ & Temperatur $\left(85-86^{\circ} \mathrm{C}\right)$ & $\begin{array}{c}\text { Kebocoran equipment } \\
\text { (tidak ada) }\end{array}$ & $\begin{array}{c}\text { Preparation indeks } \\
(>89)\end{array}$ \\
\hline Kapasitas (sesuai kuota) & Pol Baggasse $(<1,2)$ & $\begin{array}{c}\text { Jumlah hydrolic oil } \\
\text { (monitor) }\end{array}$ & $\begin{array}{c}\text { Kebersihan cane yard } \\
\text { (selalu bersih) }\end{array}$ \\
\hline $\begin{array}{c}\text { Pressure boiler }(28-30 \\
\left.\mathrm{kg} / \mathrm{cm}^{2}\right)\end{array}$ & $\begin{array}{c}\text { Sanitasi mill }(\text { sesuai } \\
\text { prosedur) }\end{array}$ & & \\
\hline $\begin{array}{c}\text { Temperature boiler } \\
\left(340-380^{\circ} \mathrm{C}\right)\end{array}$ & & & \\
\hline $\begin{array}{c}\text { Water drum level boiler } \\
(\text { normal) }\end{array}$ & & & \\
\hline
\end{tabular}

Tabel 2. Pengukuran pemahaman karyawan

\begin{tabular}{|c|l|}
\hline $\mathbf{Q}$ & \multicolumn{1}{|c|}{ Pernyataan } \\
\hline $\mathbf{1}$ & \multicolumn{1}{c|}{ SOP } \\
\hline $\mathrm{q} 1=$ & Anda menerapkan job description selama bekerja \\
\hline $\mathrm{q} 2=$ & Anda menguasai SOP yang terkait dengan pekerjaan anda \\
\hline $\mathrm{q} 3=$ & SOP mesin/peralatan kerja sesuai dengan job description anda \\
\hline $\mathrm{q} 4=$ & Anda selalu menjalankan SOP sesuai dengan job description anda \\
\hline $\mathrm{q} 5=$ & $\begin{array}{l}\text { Terdapat kesesuaian antara pengalaman kerja dengan pelaksanaan SOP dalam pekerjaan } \\
\text { anda di penggilingan saat ini }\end{array}$ \\
\hline $\mathbf{2}$ & \multicolumn{1}{c|}{ Kinerja } \\
\hline $\mathrm{q} 6=$ & Untuk meningkatkan kinerja karyawan diperlukan penyegaran berupa pelatihan \\
\hline $\mathrm{q} 7=$ & Pergiliran waktu kerja/shift mempengaruhi kinerja anda \\
\hline $\mathrm{q} 8=$ & Penghargaan (bonus dan kenaikan gaji) dari pekerjaan dapat memotivasi kinerja anda \\
\hline $\mathrm{q} 9=$ & $\begin{array}{l}\text { Jika ada penghargaan dalam prestasi kerja perlu ada sanksi atas kelalaian dalam bekerja } \\
\text { Kejenuhan dalam rutinitas pekerjaan dapat menyebabkan kinerja anda menurun }\end{array}$ \\
\hline
\end{tabular}


Tabel 2. (Lanjutan)

\begin{tabular}{|c|l|}
\hline $\mathbf{3}$ & \multicolumn{1}{c|}{ Hubungan Kerja } \\
\hline $\mathrm{q} 11=$ & $\begin{array}{l}\text { Pengganti teman sekerja sangat diperlukan jika anda mendapat halangan untuk tidak masuk } \\
\text { kerja }\end{array}$ \\
\hline $\mathrm{q} 12=$ & Hubungan kerja selama di kantor juga mempengaruhi hubungan sosial di luar kantor \\
\hline $\mathrm{q} 13=$ & $\begin{array}{l}\text { Fasilitas yang disediakan perusahaan (perumahan, pendidkan anak, sarana hiburan) } \\
\text { memotivasi anda untuk lebih loyal dan giat bekerja }\end{array}$ \\
\hline $\mathrm{q} 14=$ & $\begin{array}{l}\text { Bila terjadi konflik antar teman, anda turut berperan dalam usaha pendamaian sehingga } \\
\text { suasana kerja kembali kondusif }\end{array}$ \\
\hline $\mathrm{q} 15=$ & Peningkatan karier selalu ditentukan oleh masa kerja dan penilaian tahunan oleh atasan anda \\
\hline $\mathbf{4}$ & KPI \\
\hline $\mathrm{q} 16=$ & $\begin{array}{l}\text { Pembekalan teori dari pimpinan akan meningkatkan tugas pokok anda dalam pengoperasian } \\
\text { kegiatan gilingan untuk mencapai } K P I\end{array}$ \\
\hline $\mathrm{q} 17=$ & Koordinasi antar seksi/bagian sangat diperlukan dalam pencapaian $K P I$ \\
\hline $\mathrm{q} 18=$ & $\begin{array}{l}\text { Selain pembekalan teori/petunjuk kerja dari pimpinan, pengawasan oleh pimpinan dalam } \\
\text { operasional penggilingan dapat menentukan pencapaian } K P I\end{array}$ \\
\hline $\mathrm{q} 19=$ & $\begin{array}{l}\text { Pimpinan anda mempertimbangkan saran anda untuk meningkatkan kinerja operasional } \\
\text { penggilingan demi tercapainya } K P I\end{array}$ \\
\hline $\mathrm{q} 20=$ & Anda berperan dalam pencapaian target $K P I$ \\
\hline $\mathrm{q} 21=$ & Pasokan tonase tebu dari kebun yang bervariasi akan mempengaruhi pencapaian target $K P I$ \\
\hline $\mathrm{q} 22=$ & $\begin{array}{l}\text { Kualitas pengisian tebu untuk penggilingan mempengaruhi pencapaian target } K P I ? \text { (Seperti } \\
\text { ketebalan, kerataan, kepadatan, dan komposisi pengisian tebu) }\end{array}$ \\
\hline $\mathrm{q} 23=$ & $\begin{array}{l}\text { Sikap dan keteladanan pimpinan anda mempengaruhi kekompakan karyawan dalam } \\
\text { mencapai target } K P I\end{array}$ \\
\hline $\mathrm{q} 24=$ & Pencapaian target $K P I$ mempengaruhi besaran bonus anda \\
\hline $\mathrm{q} 25=$ & $\begin{array}{l}\text { Peralatan } K 3 \text { sudah sesuai dengan kebutuhan operasional anda dalam bekerja, sehingga } \\
\text { anda merasa aman dan nyaman untuk mencapai target } K P I\end{array}$ \\
\hline $\mathbf{5}$ & Aspek Teknisi \\
\hline $\mathrm{q} 26=$ & Perusahaan merespon terhadap kasus kecelakaan yang terjadi \\
\hline $\mathrm{q} 27=$ & $\begin{array}{l}\text { Berdasarkan pengalaman anda selama bekerja di penggilingan, dirasakan stelan gilingan } \\
\text { perlu dimodifikasi }\end{array}$ \\
\hline $\mathrm{q} 28=$ & Bundle cane akan lebih mengurangi keausan peralatan giling dibanding loose cane \\
\hline $\mathrm{q} 29=$ & Dalam pelaksanaanya, suplai tebu selalu sesuai dengan stelan kapasitas gilingan \\
\hline
\end{tabular}

Untuk membandingkan rerata pemahaman karyawan terhadap faktor-faktor yang mempengaruhi kinerja digunakan uji statistik LSD (Least Significant Difference) sedangkan untuk mengetahui faktor-faktor yang mempengaruhi kinerja digunakan analisis regresi dengan model sebagai berikut.

\footnotetext{
Kinerja $=\alpha_{0}+\alpha_{1}$ Pemahaman Jobdis - SOP + $\alpha_{2}$ Pemahaman Kinerja + $\alpha_{3}$ Pemahaman Hubungan Kerja + $\alpha_{4}$ Pemahaman KPI $+\alpha_{5}$ Pemahaman Aspek Teknis $+\mu$
}

\section{HASIL DAN PEMBAHASAN}

\section{Validitas dan Reliabilitas Instrumen}

Data yang terkait dengan faktor penentu kinerja karyawan Divisi Mill dan Boiler dikumpulkan melalui wawancara dengan karyawan di divisi tersebut. Instrumen atau kuesioner yang digunakan untuk pengumpulan data mencakup pemahaman terhadap (i) standard operating procedure (SOP) terdiri atas 5 pernyataan, (ii) kinerja 5 pernyataan, (iii) hubungan kerja 5 pernyataan, (iv) key performance indicator (KPI) 10 pernyataan, dan (v) aspek teknis 5 pernyataan (Tabel 3). 
Tabel 3. Hasil Uji Validitas dan Reliabilitas

\begin{tabular}{|c|c|c|c|c|c|c|c|c|c|}
\hline \multicolumn{2}{|c|}{ Jobdis dan SOP } & \multicolumn{2}{c|}{ Kinerja } & \multicolumn{2}{c|}{ Hubungan Kerja } & \multicolumn{2}{c|}{ KPI } & \multicolumn{2}{c|}{ Aspek Teknis } \\
\hline $\mathrm{q} 1$ & $0.269^{*}$ & $\mathrm{q} 6$ & $0.252^{*}$ & $\mathrm{q} 11$ & $.544^{* * *}$ & $\mathrm{q} 16$ & $.283^{* *}$ & $\mathrm{q} 26$ & $0.265^{*}$ \\
\hline $\mathrm{q} 2$ & $.304^{* *}$ & $\mathrm{q} 7$ & $0.253^{*}$ & $\mathrm{q} 12$ & $.396^{* * *}$ & $\mathrm{q} 17$ & $.387^{* * *}$ & $\mathrm{q} 27$ & $.287^{* *}$ \\
\hline $\mathrm{q} 3$ & $.424 * * *$ & $\mathrm{q} 8$ & $.289^{* *}$ & $\mathrm{q} 13$ & $.414^{* * *}$ & $\mathrm{q} 18$ & $.423^{* * *}$ & $\mathrm{q} 28$ & $.494^{* * *}$ \\
\hline $\mathrm{q} 4$ & $0.235^{*}$ & $\mathrm{q} 9$ & $0.26^{*}$ & $\mathrm{q} 14$ & $.367^{* * *}$ & $\mathrm{q} 19$ & $.324^{* *}$ & $\mathrm{q} 29$ & $.446^{* * *}$ \\
\hline $\mathrm{q} 5$ & $.407^{* * *}$ & $\mathrm{q} 10$ & $.304^{* *}$ & $\mathrm{q} 15$ & $.287^{* *}$ & $\mathrm{q} 20$ & $0.271^{*}$ & $\mathrm{q} 30$ & $.321^{* *}$ \\
\hline & & & & & & $\mathrm{q} 21$ & $.513^{* * *}$ & & \\
\hline & & & & & & $\mathrm{q} 22$ & $.409 * * *$ & & \\
\hline & & & & & & $\mathrm{q} 23$ & $.360^{* * *}$ & & \\
\hline & & & & & & $\mathrm{q} 24$ & $0.254^{*}$ & & \\
\hline & & & & & & $\mathrm{q} 25$ & $.463^{* * *}$ & & \\
\hline Alpha & 0.566 & Alpha & 0.500 & Alpha & 0.503 & Alpha & 0.533 & Alpha & 0.510 \\
\hline
\end{tabular}

*) signifikan pada tingkat kesalahan $10 \%$

**) signifikan pada tingkat kesalahan $5 \%$

$* * *$ ) signifikan pada tingkat kesalahan $1 \%$

\section{Kinerja Karyawan}

Penilaian kinerja karyawan di Divisi Mill dan Boiler berbeda menurut tingkat jabatan yang ada di divisi tersebut, yaitu (i) chief dan officer, (ii) mill supervisor, (iii) mill mechanic supervisor, dan (iv) cane handling supervisor.

Kinerja chief dan officer dinilai berdasarkan prestasinya dalam mengendalikan (i) pol baggasse di bawah 1,2, (ii) moisture baggasse di bawah 47, (iii) kapasitas sesuai kuota, (iv) pressure boiler antara $28-30 \mathrm{~kg} / \mathrm{cm}^{2}$, (v) temperatur boiler antara $340-380^{\circ} \mathrm{C}$, dan water drum level boiler dalam keadaan normal. Dari komponen kinerja tersebut, kapasitas, pressure boiler, temperature boiler, dan water drum level boiler dapat tercapai 100 persen (Tabel 4).

Rerata dalam setahun capaian pol baggasse dan moisture baggasse masing-masing hanya tercapai 14,41 dan 28,13 persen. Secara keseluruhan kinerja chief dan officer di Divisi Mill dan Boiler dapat dikategorikan baik dengan capaian 73,50 persen. Kinerja mill supervisor dinilai berdasarkan prestasinya dalam mengendalikan (i) imbibisi di atas $220 \%$, (ii) temperature antara $85-86^{\circ} \mathrm{C}$, (iii) pol baggasse kurang dari 1,2, dan (iv) sanitasi mill sesuai prosedur. Dari komponen kinerja yang ada, imbibisi, temperature, dan sanitasi mill dapat

Tabel 4. Rerata Kinerja Chief dan Officer Mill dan Boiler per Bulan Tahun 2013 (\%)

\begin{tabular}{|c|c|c|c|c|c|c|c|c|c|}
\hline \multirow[t]{2}{*}{ Komponen } & \multicolumn{8}{|c|}{ Bulan } & \multirow{2}{*}{ Rerata } \\
\hline & April & Mei & Juni & Juli & Agst & Sept & Okt & Nov & \\
\hline $\begin{array}{l}\text { Pol Baggasse } \\
(<1,2)\end{array}$ & 51.39 & 2.22 & 25.56 & 21.67 & 6.67 & 3.33 & 0.00 & 4.45 & 14.41 \\
\hline $\begin{array}{l}\text { Moisture Baggasse } \\
(<47)\end{array}$ & 33.33 & 46.67 & 20.00 & 19.44 & 16.67 & 14.45 & 40.00 & 34.45 & 28.13 \\
\hline $\begin{array}{l}\text { Kapasitas } \\
\text { (sesuai kuota) }\end{array}$ & 100.00 & 100.00 & 100.00 & 100.00 & 100.00 & 100.00 & 100.00 & 100.00 & 100.00 \\
\hline $\begin{array}{l}\text { Pressure boiler } \\
\left(28-30 \mathrm{~kg} / \mathrm{cm}^{2}\right) \\
\end{array}$ & 00.00 & 100.00 & 100.00 & 100.00 & 100.00 & 100.00 & 100.00 & 100.00 & 100.00 \\
\hline $\begin{array}{l}\text { Temperature boiler } \\
\left(340-380^{\circ} \mathrm{C}\right)\end{array}$ & 94.44 & 100 & 100.00 & 100.00 & 100.00 & 97.78 & 100.00 & 00 & 9.03 \\
\hline $\begin{array}{l}\text { Water drum level } \\
\text { boiler (normal) }\end{array}$ & 100.00 & 100.00 & 100.00 & 100.00 & 100.00 & 10 & 100.00 & 100.00 & 100.00 \\
\hline Rerata & 79.12 & 74.81 & 74.26 & 73.52 & 70.56 & 69.26 & 73.33 & 73.15 & 73.50 \\
\hline
\end{tabular}


tercapai 100 persen (Tabel 5). Seperti pada Chief dan Officer capaian pol baggasse masih rendah yaitu 15,49 persen. Secara keseluruhan kinerja mill supervisor termasuk kategori baik dengan rerata capaian 78,87 persen.

Kinerja mill mechanic supervisor dinilai berdasarkan prestasinya dalam mengendalikan (i) kondisi equipment di mill (siap operasional), (ii) tidak ada kebocoran equipment, (iii) dan jumlah hydrolic oil termonitor. Tabel 6 menunjukkan bahwa masing-masing komponen kinerja mill mechanic supervisor sepenuhnya terpenuhi.

Kinerja cane handling supervisor dinilai berdasarkan prestasinya dalam mengendalikan (i) cane yard berdasar prinsip FIFO, (ii) preparation index lebih dari 89, dan (iii) kebersihan cane yard terjaga. Tabel 7 menunjukkan bahwa masingmasing komponen kinerja cane handling supervisor sepenuhnya terpenuhi.

\section{Pemahaman Terhadap Faktor Penentu Kinerja}

Kenerja karyawan di suatu perusahaan ditentukan oleh berbagai faktor antara lain pemahaman karyawan terhadap (i) SOP, (ii) hubungan kerja, (iii) KPI, (iv) aspek teknis pekerjaan, dan (v) kinerja karyawan. Diperkirakan semakin tinggi pemahaman karyawan terhadap penentu factor kinerja semakin tinggi kinerja karyawan.

Pemahaman pimpinan dan karyawan terhadap SOP dinilai dengan 5 pernyataan, q1 sampai dengan q5 (Tabel 8). Pada umumnya pimpinan dan karyawan di Divisi Mill dan Boiler telah memhami SOP, dan menyatakan adanya kesesuaian antara SOP dengan pekerjaannya. Namun demikian, pimpinan dan karyawan belum sepenuhnya memahami adanya hubungan antara pengalaman kèrja dengan SOP. Hal ini karena adanya perkembangan SOP, sementara itu karyawan belum sempat melakukan penyesuaian. Secara keseluruhan pemhaman pimpinan dan karyawan terhadap SOP tergolong baik ditunjukkan oleh skor sebesar 2,73. Pemahaman pimpinan terhadap SOP lebih tinggi dari karyawan mill dan boiler. Di samping itu dapat dikemukakan bahwa pemahaman karyawan mill dan karyawan boiler tidak berbeda.

Tabel 5. Rerata Kinerja Mill Supervisor per Bulan Tahun 2013 (\%)

\begin{tabular}{|l|c|c|c|c|c|c|c|c|c|}
\hline \multirow{2}{*}{ Komponen } & \multicolumn{7}{|c|}{ Bulan } & \multirow{2}{*}{ Rerata } \\
\cline { 2 - 10 } & April & Mei & Juni & Juli & Agst & Sept & Okt & Nov & 100.00 \\
\hline $\begin{array}{l}\text { Imbibisi \% fiber } \\
(>220 \%)\end{array}$ & 100.00 & 100.00 & 100.00 & 100.00 & 100.00 & 100.00 & 100.00 & 100.00 & 100 \\
\hline $\begin{array}{l}\text { Temperatur } \\
\left(85-86^{\circ} \mathrm{C}\right)\end{array}$ & 100.00 & 100.00 & 100.00 & 100.00 & 100.00 & 100.00 & 100.00 & 100.00 & 100.00 \\
\hline $\begin{array}{l}\text { Pol Baggasse } \\
(<1,2)\end{array}$ & 97.22 & 0.00 & 11.11 & 4.44 & 4.44 & 2.22 & 2.22 & 2.22 & 15.49 \\
\hline $\begin{array}{l}\text { Sanitasi mill } \\
\text { (sesuai prosedur) }\end{array}$ & 100.00 & 100.00 & 100.00 & 100.00 & 100.00 & 100.00 & 100.00 & 100.00 & 100.00 \\
\hline \multicolumn{1}{|c|}{ Rerata } & 99.31 & 75.00 & 77.78 & 76.11 & 76.11 & 75.56 & 75.56 & 75.56 & 78.87 \\
\hline
\end{tabular}

Tabel 6. Rerata Kinerja Mill Mechanic Supervisor per Bulan Tahun 2013 (\%)

\begin{tabular}{|l|c|c|c|c|c|c|c|c|c|}
\hline \multirow{2}{*}{ Komponen } & \multicolumn{7}{|c|}{ Bulan } & \multirow{2}{*}{ Rerata } \\
\cline { 2 - 10 } & April & Mei & Juni & Juli & Agst & Sept & Okt & Nov & \\
\hline $\begin{array}{l}\text { Kondisi equipment } \\
\text { di mill } \\
\text { (siap operasional) }\end{array}$ & 100.00 & 100.00 & 100.00 & 100.00 & 100.00 & 100.00 & 100.00 & 100.00 & 100.00 \\
\hline $\begin{array}{l}\text { Kebocoran } \\
\text { equipment } \\
\text { (tidak ada) }\end{array}$ & 100.00 & 100.00 & 100.00 & 100.00 & 100.00 & 100.00 & 100.00 & 100.00 & 100.00 \\
\hline $\begin{array}{l}\text { Jumlah hydrolic oil } \\
\text { (monitor) }\end{array}$ & 100.00 & 100.00 & 100.00 & 100.00 & 100.00 & 100.00 & 100.00 & 100.00 & 100.00 \\
\hline \multicolumn{1}{c}{ Rerata } & 100.00 & 100.00 & 100.00 & 100.00 & 100.00 & 100.00 & 100.00 & 100.00 & 100.00 \\
\hline
\end{tabular}


Tabel 7. Rerata kinerja Cane Handling Supervisor Tahun 2013 (\%)

\begin{tabular}{|l|c|c|c|c|c|c|c|c|c|}
\hline \multirow{2}{*}{ Komponen } & \multicolumn{7}{|c|}{ Bulan } & \multirow{2}{*}{ Rerata } \\
\cline { 2 - 10 } & April & Mei & Juni & Juli & Agst & Sept & Okt & Nov & 100.00 \\
\hline $\begin{array}{l}\text { Mengatur cane yard } \\
\text { (FIFO) }\end{array}$ & 100.00 & 100.00 & 100.00 & 100.00 & 100.00 & 100.00 & 100.00 & 100.00 & 100.00 \\
\hline $\begin{array}{l}\text { Preparation indeks } \\
(>89)\end{array}$ & 100.00 & 100.00 & 100.00 & 100.00 & 100.00 & 100.00 & 100.00 & 100.00 & 100.00 \\
\hline $\begin{array}{l}\text { Kebersihan cane } \\
\text { yard (selalu bersih) }\end{array}$ & 100.00 & 100.00 & 100.00 & 100.00 & 100.00 & 100.00 & 100.00 & 100.00 & 100.00 \\
\hline \multicolumn{1}{|c|}{ Rerata } & 100.00 & 100.00 & 100.00 & 100.00 & 100.00 & 100.00 & 100.00 & 100.00 & 100.00 \\
\hline
\end{tabular}

Tabel 8. Pemahaman Karyawan Cane, Karyawan Mill, dan Pimpinan Terhadap SOP

\begin{tabular}{|l|c|c|c|c|c|c|}
\hline \multicolumn{1}{|c|}{ Kelompok } & $\mathrm{q} 1$ & $\mathrm{q} 2$ & $\mathrm{q} 3$ & $\mathrm{q} 4$ & $\mathrm{q} 5$ & Rerata \\
\hline Pimpinan & 3.00 & 3.00 & 3.00 & 3.00 & 3.00 & 3.00 \\
\hline Karyawan Boiler & 2.92 & 2.96 & 2.76 & 2.68 & 2.28 & 2.72 \\
\hline Karyawan Mill & 2.90 & 2.86 & 2.67 & 2.81 & 2 & 2.65 \\
\hline Rerata & 2.92 & 2.92 & 2.75 & 2.77 & 2.26 & 2.73 \\
\hline Uji Rerata (LSD) & & & & & & \\
\hline Pimpinan-Karyawan Boiler & $\mathrm{n}-\mathrm{s}$ & $\mathrm{n}-\mathrm{s}$ & $\mathrm{n}-\mathrm{s}$ & $\mathrm{n}-\mathrm{s}$ & $*$ & $* *$ \\
\hline Pimpinan -Karyawan Mill & $\mathrm{n}-\mathrm{s}$ & $\mathrm{n}-\mathrm{s}$ & $\mathrm{n}-\mathrm{s}$ & $\mathrm{n}-\mathrm{s}$ & $* * *$ & $* * *$ \\
\hline Karyawan Boiler-Karyawan Mill & $\mathrm{n}-\mathrm{s}$ & $\mathrm{n}-\mathrm{s}$ & $\mathrm{n}-\mathrm{s}$ & $\mathrm{n}-\mathrm{s}$ & $\mathrm{n}-\mathrm{s}$ & $\mathrm{n}-\mathrm{s}$ \\
\hline
\end{tabular}

$*=$ nyata pada tingkat kesalahan $10 \%$

$* *=$ nyata pada tingkat kesalahan $5 \%$

$* * *=$ nyata pada tingkat kesalahan $1 \%$

$\mathrm{q} 1=$. Anda menerapkan job description selama bekerja

$\mathrm{q} 2=$ Anda menguasai $S O P$ yang terkait dengan pekerjaan anda

$\mathrm{q} 3=$ SOP mesin/peralatan kerja sesuai dengan job description anda

$\mathrm{q} 4=$ Anda selalu menjalankan $S O P$ sesuai dengan job description anda

$\mathrm{q} 5=$ Terdapat kesesuaian antara pengalaman kerja dengan pelaksanaan $S O P$ dalam pekerjaan anda di penggilingan saat ini

Pemahaman pimpinan dan karyawan terhadap kinerja dinilai dengan 5 pernyataan, q6 sampai dengan q10 (Tabel 9). Pada umumnya pimpinan dan karyawan di Divisi Mill dan Boiler telah memhami bahwa penyegaran dalam bentuk pelatihan dan penghargaan dalam bentuk bonus dan kenaikan gaji dapat dapat meningkatkan kinerja. Namun demikian, pimpinan dan karyawan belum sepenuhnya memahami bahwa pergiliran kerja/shift, pemberian sangsi dan penghargaan, dan rutinitas kerja dapat mempengaruhi kinerja. Secara keseluruhan pemahaman pimpinan dan karyawan terhadap kinerja tergolong sedang ditunjukkan oleh skor sebesar 2,42. Pemahaman pimpinan terhadap kinerja lebih tinggi dari karyawan mill dan karyawan boiler. Di samping itu dapat dikemukakan bahwa tidak ada perbedaan pemahaman terhadap kinerja antara karywan mill dan karyawan boiler.

Pemahaman pimpinan dan karyawan terhadap hubungan kerja dinilai dengan 5 pernyataan, q11 sampai dengan q15 (Tabel 10). Pada umumnya pimpinan dan karyawan di Divisi Mill dan Boiler telah memahami pentingnya hubungan kerja yang baik antar karyawan untuk saling menggantikan bila diperlukan, menyelesaikan konflik, meniti karir, dan sebagainya. Namun demikian pimpinan dan karyawan di Divisi Mill dan Boiler belum sepenuhnya memahami bahwa ada kaitan antara hubungan kerja di kantor dengan hubungan sosial di luar kantor. Secara keseluruhan pemahaman pimpinan dan karyawan terhadap hubungan kerja 
Tabel 9. Pemahaman Karyawan Mill, Karyawan Boiler, dan Pimpinan Terhadap Kinerja

\begin{tabular}{|l|c|c|c|c|c|c|}
\hline \multicolumn{1}{|c|}{ Kelompok } & $\mathrm{q} 6$ & $\mathrm{q} 7$ & $\mathrm{q} 8$ & $\mathrm{q} 9$ & $\mathrm{q} 10$ & Rerata \\
\hline Pimpinan & 3.00 & 2.83 & 3.00 & 3.00 & 3.00 & 2.97 \\
\hline Karyawan Boiler & 2.72 & 1.80 & 2.84 & 2.52 & 2.00 & 2.38 \\
\hline Karyawan Mill & 2.62 & 1.38 & 2.81 & 2.43 & 2.24 & 2.30 \\
\hline Rerata & 2.72 & 1.77 & 2.85 & 2.55 & 2.22 & 2.42 \\
\hline Uji Rerata (LSD) & & & & & & \\
\hline Pimpinan-Karyawan Boiler & $\mathrm{n}-\mathrm{s}$ & $* * *$ & $\mathrm{n}-\mathrm{s}$ & $\mathrm{n}-\mathrm{s}$ & $* * *$ & $* * *$ \\
\hline Pimpinan-Karyawan Mill & $\mathrm{n}-\mathrm{s}$ & $* * *$ & $\mathrm{n}-\mathrm{s}$ & $*$ & $*$ & $* * *$ \\
\hline Karyawan Cane-Karyawan Mill & $\mathrm{n}-\mathrm{s}$ & $*$ & $\mathrm{n}-\mathrm{s}$ & $\mathrm{n}-\mathrm{s}$ & $\mathrm{n}-\mathrm{s}$ & $\mathrm{n}-\mathrm{s}$ \\
\hline
\end{tabular}

$\mathrm{n}$-s = tidak nyata

$*=$ nyata pada tingkat kesalahan $10 \%$

$* *=$ nyata pada tingkat kesalahan $5 \%$

$* * *=$ nyata pada tingkat kesalahan $1 \%$

q6 $=$ Untuk meningkatkan kinerja karyawan diperlukan penyegaran berupa pelatihan

q7 $=$ Pergiliran waktu kerja/shift mempengaruhi kinerja anda

q8 = Penghargaan (bonus dan kenaikan gaji) dari pekerjaan dapat memotivasi kinerja anda

$\mathrm{q} 9=$ Jika ada penghargaan dalam prestasi kerja perlu ada sanksi atas kelalaian dalam

$\mathrm{q} 10=$ Kejenuhan dalam rutinitas pekerjaan dapat menyebabkan kinerja anda menurun

Tabel 10. Pemahaman Karyawan Cane, Karyawan Mill, dan Pimpinan Terhadap Hubungan Kerja

\begin{tabular}{|c|r|r|r|r|r|r|}
\hline Kelompok & \multicolumn{1}{|c|}{$\mathrm{q} 11$} & \multicolumn{1}{|c|}{$\mathrm{q} 12$} & \multicolumn{1}{c|}{$\mathrm{q} 13$} & $\mathrm{q} 14$ & \multicolumn{1}{c|}{$\mathrm{q} 15$} & \multicolumn{1}{c|}{ Rerata } \\
\hline Pimpinan & 3.00 & 3.00 & 3.00 & 3.00 & 3.00 & 3.00 \\
\hline Kryawan Boiler & 3.00 & 2.16 & 2.8 & 2.76 & 2.72 & 2.69 \\
\hline Karyawan Mill & 2.95 & 2.35 & 2.85 & 2.95 & 2.55 & 2.74 \\
\hline Rerata & 2.98 & 2.34 & 2.84 & 2.86 & 2.69 & 2.75 \\
\hline Uji Rerata (LSD) & & & & & & \\
\hline Pimpinan-Karyawan Boiler & $\mathrm{n}-\mathrm{s}$ & $* * *$ & $\mathrm{n}-\mathrm{s}$ & $\mathrm{n}-\mathrm{s}$ & $\mathrm{n}-\mathrm{s}$ & $* * *$ \\
\hline Pimpinan-Karyawan Mill & $\mathrm{n}-\mathrm{s}$ & $*$ & $\mathrm{n}-\mathrm{s}$ & $\mathrm{n}-\mathrm{s}$ & $\mathrm{n}-\mathrm{s}$ & $* * *$ \\
\hline Karyawan Boiler-Karyawan Mill & $\mathrm{n}-\mathrm{s}$ & $\mathrm{n}-\mathrm{s}$ & $\mathrm{n}-\mathrm{s}$ & $\mathrm{n}-\mathrm{s}$ & $\mathrm{n}-\mathrm{s}$ & $\mathrm{n}-\mathrm{s}$ \\
\hline
\end{tabular}

n-s = tidak nyata

$*=$ nyata pada tingkat kesalahan $10 \%$

$* *=$ nyata pada tingkat kesalahan $5 \%$

$* * *=$ nyata pada tingkat kesalahan $1 \%$
$\mathrm{q} 11=\begin{aligned} & \text { Pengganti teman sekerja sangat diperlukan jika anda mendapat halangan untuk tidak } \\ & \text { masuk kerja }\end{aligned}$
$\mathrm{q} 12=$ Hubungan kerja selama di kantor juga mempengaruhi hubungan sosial di luar kantor
$\mathrm{q} 13=$ Fasilitas yang disediakan perusahaan (perumahan, pendidkan anak, sarana hiburan) memotivasi anda untuk lebih loyal dan giat bekerja
$\mathrm{q} 14=$ Bila terjadi konflik antar teman, anda turut berperan dalam usaha pendamaian sehingga suasana kerja kembali kondusif
$\mathrm{q} 15=\begin{aligned} & \text { Peningkatan karier selalu ditentukan oleh masa kerja dan penilaian tahunan oleh atasan } \\ & \text { anda }\end{aligned}$

tergolong baik ditunjukkan oleh skor sebesar 2,75. Pemahaman pimpinan terhadap hubungan kerja lebih tinggi dari karyawan cane dan karyawan mill. Di samping itu dapat dikemukakan bahwa tidak ada perbedaan pemahaman terhadap hubungan kerja antara karyawan mill dan karyawan boiler. 
Pemahaman pimpinan dan karyawan terhadap KPI dinilai dengan 10 pernyataan, q16 sampai dengan q25 (Tabel 11). Pada umumnya pimpinan dan karyawan di Divisi Mill dan Boiler telah memahami pentingnya pembekalan teori, koordinasi antar bagian, petunjuk kerja dan pengawasan oleh pimpinan, pimpinan memperhatikan saran dari bawahan, peran karyawan dalam pencapaian KPI, keteladanan pimpinan, kuantitas pasokan tebu, kualitas pasokan tebu, dan besarnya bonus untuk mencapai KPI yang ditetatapkan perusahaan. Namun demikian pimpinan dan karyawan belum memahami pentingnya kelengkapan $\mathrm{K} 3$ untuk mencapai KPI yang ditetapkan perusahaan. Secara keseluruhan pemahaman pimpinan dan karyawan terhadap hubungan kerja tergolong baik ditunjukkan oleh skor sebesar 2,78. Pemahaman pimpinan terhadap KPI lebih tinggi dari karyawan boiler dan karyawan mill. Di samping itu dapat dikemukakan bahwa tidak ada perbedaan pemahaman terhadap KPI antara karywan boiler dan karyawan mill.

Pemahaman pimpinan dan karyawan terhadap aspek teknis dinilai dengan 5 pernyataan, q26 sampai dengan q30 (Tabel 12). Pada umumnya pimpinan dan karyawan di Divisi Mill dan Boiler telah memahami pentingnya pencegahan kecelakaan kerja, pengaruh bundle cane dan loose cane terhadap keausan peralatan dan pengadaan sparepart. Namun demikian pimpinan dan karyawa Divisi Mill dan Boiler

Tabel 11. Pemahaman Karyawan Boiler, Karyawan Mill, dan Pimpinan Terhadap KPI

\begin{tabular}{|l|r|r|r|r|r|r|r|r|r|r|r|}
\hline \multicolumn{1}{|c|}{ Kelompok } & $\mathrm{q} 16$ & $\mathrm{q} 17$ & $\mathrm{q} 18$ & $\mathrm{q} 19$ & $\mathrm{q} 20$ & $\mathrm{q} 21$ & $\mathrm{q} 22$ & $\mathrm{q} 23$ & $\mathrm{q} 24$ & $\mathrm{q} 25$ & Rerata \\
\hline Pimpinan & 3.00 & 3.00 & 3.00 & 3.00 & 3.00 & 3.00 & 3.00 & 3.00 & 3.00 & 3.00 & 3.00 \\
\hline Karyawan Boiler & 3.00 & 2.96 & 2.76 & 2.52 & 2.8 & 2.76 & 2.96 & 2.96 & 2.6 & 1.96 & 2.73 \\
\hline Karyaman Mill & 2.86 & 2.95 & 2.90 & 2.65 & 2.81 & 2.62 & 2.90 & 2.86 & 2.81 & 2.28 & 2.76 \\
\hline Rerata & 2.94 & 2.96 & 2.85 & 2.63 & 2.83 & 2.74 & 2.94 & 2.92 & 2.73 & 2.22 & 2.78 \\
\hline Uji Rerata (LSD & & & & & & & & & & & \\
\hline $\begin{array}{l}\text { Pimpinan- } \\
\text { Karyawan Boiler }\end{array}$ & $\mathrm{n}-\mathrm{s}$ & $\mathrm{n}-\mathrm{s}$ & $\mathrm{n}-\mathrm{s}$ & $* *$ & $\mathrm{n}-\mathrm{s}$ & $\mathrm{n}-\mathrm{s}$ & $\mathrm{n}-\mathrm{s}$ & $\mathrm{n}-\mathrm{s}$ & $\mathrm{n}-\mathrm{s}$ & $* * *$ & $* * *$ \\
\hline $\begin{array}{l}\text { Pimpinan- } \\
\text { Karyawan Mill }\end{array}$ & $\mathrm{n}-\mathrm{s}$ & $\mathrm{n}-\mathrm{s}$ & $\mathrm{n}-\mathrm{s}$ & $\mathrm{n}-\mathrm{s}$ & $\mathrm{n}-\mathrm{s}$ & $\mathrm{n}-\mathrm{s}$ & $\mathrm{n}-\mathrm{s}$ & $\mathrm{n}-\mathrm{s}$ & $\mathrm{n}-\mathrm{s}$ & $* *$ & $* *$ \\
\hline $\begin{array}{l}\text { Karyawan Boiler- } \\
\text { Karyawan Mill }\end{array}$ & $* *$ & $\mathrm{n}-\mathrm{s}$ & $\mathrm{n}-\mathrm{s}$ & $\mathrm{n}-\mathrm{s}$ & $\mathrm{n}-\mathrm{s}$ & $\mathrm{n}-\mathrm{s}$ & $\mathrm{n}-\mathrm{s}$ & $\mathrm{n}-\mathrm{s}$ & $\mathrm{n}-\mathrm{s}$ & $\mathrm{n}-\mathrm{s}$ & $\mathrm{n}-\mathrm{s}$ \\
\hline
\end{tabular}

$\mathrm{n}-\mathrm{s}=$ tidak nyata

$*=$ nyata pada tingkat kesalahan $10 \%$

$* *=$ nyata pada tingkat kesalahan $5 \%$

$* * *=$ nyata pada tingkat kesalahan $1 \%$

$\mathrm{q} 16=$

$\mathrm{q} 17=$

$\mathrm{q} 18=$

$\mathrm{q} 19=$

$\mathrm{q} 20=$

q21 = Pasokan tonase tebu dari kebun yang bervariasi akan mempengaruhi pencapaian target $K P I$

$\mathrm{q} 22=$

$\mathrm{q} 23=$

q24= Pencapaian target $K P I$ mempengaruhi besaran bonus anda

q25 = Peralatan $K 3$ sudah sesuai dengan kebutuhan operasional anda dalam bekerja, sehingga anda merasa aman dan nyaman untuk mencapai target $K P I$ 
belum sepenuhnya memahami pentingnya kesesuaian antara stelan gilingan dengan pasokan tebu. Secara keseluruhan pemahaman pimpinan dan karyawan terhadap aspek teknis tergolong baik ditunjukkan oleh skor sebesar 2,58. Pemahaman pimpinan terhadap aspek teknis lebih tinggi dari karyawan boiler dan karyawan mill. Di samping itu dapat dikemukakan bahwa tidak ada perbedaan pemahaman terhadap aspek teknis antara karyawan boiler dan karyawan mill.
Dari lima faktor penentu kinerja karyawan Divisi Mill dan Boiler terdapat dua faktor yang pengaruhnya nyata terhadap kinerja karyawan yaitu pemahaman terhadap SOP dan pemahaman terhadap hubungan kerja. Semakin tinggi pemahaman karyawan terhadap SOP dan pehaman karyawan terhadap hubungan kerja maka semakin tinggi kinerja karyawan. Pemahaman SOP akan membawa karyawan bekerja sesuai ketentuan sehingga hasil kerjanya

Tabel 12. Pemahaman Karyawan Bolier, Karyawan Mill, dan Pimpinan Terhadap Aspek Teknis

\begin{tabular}{|l|c|c|c|c|c|c|}
\hline \multicolumn{1}{|c|}{ Kelompok } & $\mathrm{q} 26$ & $\mathrm{q} 27$ & $\mathrm{q} 28$ & $\mathrm{q} 29$ & $\mathrm{q} 30$ & Rerata \\
\hline Pimpinan & 3.00 & 2.83 & 3.00 & 3.00 & 3.00 & 2.97 \\
\hline Kryawan Boiler & 2.92 & 2.24 & 2.24 & 1.92 & 2.40 & 2.34 \\
\hline Karyawan Mill & 3.00 & 2.04 & 2.52 & 1.67 & 2.62 & 2.44 \\
\hline Rerata & 2.97 & 2.49 & 2.59 & 2.19 & 2.67 & 2.58 \\
\hline Uji Rerata (LSD) & & & & & & \\
\hline Pimpinan-Karyawan Boiler & $\mathrm{n}-\mathrm{s}$ & $*$ & $* *$ & $* * *$ & $* *$ & $* * *$ \\
\hline Pimpinan-Karyawan Mill & $\mathrm{n}-\mathrm{s}$ & $\mathrm{n}-\mathrm{s}$ & $\mathrm{n}-\mathrm{s}$ & $* * *$ & $\mathrm{n}-\mathrm{s}$ & $* * *$ \\
\hline Karyawan Boiler-Karyawan Mill & $\mathrm{n}-\mathrm{s}$ & $\mathrm{n}-\mathrm{s}$ & $\mathrm{n}-\mathrm{s}$ & $\mathrm{n}-\mathrm{s}$ & $\mathrm{n}-\mathrm{s}$ & $\mathrm{n}-\mathrm{s}$ \\
\hline
\end{tabular}

$\mathrm{n}$-s = tidak nyata

$*$ =nyata pada tingkat kesalahan $10 \%$

$* *=$ nyata pada tingkat kesalahan $5 \%$

$* * *=$ nyata pada tingkat kesalahan $1 \%$

q26= Perusahaan merespon terhadap kasus kecelakaan yang terjadi

$\mathrm{q} 27=$ Berdasarkan pengalaman anda selama bekerja di penggilingan, dirasakan stelan gilingan perlu dimodifikasi

$\mathrm{q} 28=$ Bundle cane akan lebih mengurangi keausan peralatan giling dibanding loose cane

q29= Dalam pelaksanaanya, suplai tebu selalu sesuai dengan stelan kapasitas gilingan

$\mathrm{q} 30=$ Anda turut berperan dalam perencanaan perbaikan dan pengadaan sparepart yang diperlukan dalam operasional penggilingan

\section{Faktor Penentu Kinerja}

Pemahaman terhadap SOP, kinerja, hubungan kerja, KPI, dan aspek tenis diperkirakan berpengaruh terhadap kinerja karyawan di Divisi Mill dan Boiler. Tabel 13 menunjukkan hasil analisis regresi fungsi kinerja karyawan. Koefisien diterminasi diperoleh sebesar 0,83895, menunjukkan bahwa 84 persen variasi kinerja karyawan dapat dijelaskan oleh faktor pemahaman karyawan terhadap SOP, kinerja, hubungan kerja, KPI, dan aspek teknis. F-hitung sebesar 9,376743 dan signifikan pada tingkat kesalahan 1persen menunjukkan bahwa secara simultan faktor SOP, kinerja, hubungan kerja, KPI, dan aspek teknis berpengaruh nyata terhadap kinerja karyawan. sesuai dengan harapan. Demikian pula hubungan kerja yang baik antar karyawan, antara karyawan dengan manajemen (ada fasilitas pendidikan, sekolah bagi anak karyawan dan keluarganya, dan sebagainya) member motivasi kepada karyawan untuk bekerja sesuai harapan.

\section{KESIMPULAN DAN SARAN}

Penilaian kinerja karyawan di Divisi Mill dan Boiler berbeda menurut tingkat jabatan yang ada di divisi tersebut, yaitu (i) chief dan officer, (ii) mill supervisor, (iii) mill mechanic supervisor, dan (iv) cane handling supervisor. Kinerja chief dan officer di Divisi Mill dan Boiler dapat dikategorikan baik dengan capaian 73,50 persen. Kinerja mill supervisor termasuk kategori 
Tabel 13. Faktor-faktor yang Mempengaruhi Kinerja Karyawan Divisi Mill dan Boiler

\begin{tabular}{|l|r|r|r|r|}
\hline \multicolumn{1}{|c|}{ Variabel } & \multicolumn{1}{c|}{ Koefisien } & $\begin{array}{c}\text { Kesalahan } \\
\text { Standar }\end{array}$ & \multicolumn{1}{c|}{ Statistik t } & \multicolumn{1}{c|}{ Probability } \\
\hline Konstan & -150.7171 & 88.31026 & -1.706677 & 0.1221 \\
\hline Pemahaman SOP & $48.19338^{* * *}$ & 5.534594 & 8.707663 & 0.0000 \\
\hline Pemahaman Kinerja & 10.14201 & 9.780122 & 1.037002 & 0.3268 \\
\hline Pemhaman Hubungan Kerja & $\left.43.20626^{*}\right)$ & 23.26471 & 1.857159 & 0.0962 \\
\hline Pemahaman KPI & -18.21888 & 19.96831 & -0.912389 & 0.3854 \\
\hline Pemahaman Aspek Teknis & -7.994029 & 4.554374 & -1.755242 & 0.1131 \\
\hline Koefisien diterminasi $\left(\mathrm{R}^{2}\right)$ & 0.838951 & & & \\
\hline F-hitung & $\left.9.376743^{* * *}\right)$ & & & \\
\hline *) signifikan pada tingkat keslahan $10 \%$ & & &
\end{tabular}

*) signifikan pada tingkat keslahan $10 \%$

${ }^{* * *}$ ) signifikan pada tingkat kesalahan $1 \%$

baik dengan rerata capaian 78,87 persen. Kinerja chief, officer, dan mill supervisor terkait erat dengan masih rendahnya capaian pol baggasse. Kinerja mill mechanic supervisor dan cane handling supervisor masing-masing capaiannya 100 persen.

\section{Faktor-faktor yang diperkirakan} berpengaruh terhadap kinerja karyawan Divisi Mill dan Boiler adalah pemahaman terhadap SOP, kinerja, hubungan kerja, KPI, dan aspek teknis. Dari lima faktor tersebut faktor yang berpengaruh nyata terhadap kinerja karyawan Divisi Mill dan Boiler adalah pemahaman terhadap SOP dan pemahaman terhadap hubungan kerja. Pemahaman terhadap SOP akan membawa karyawan bekerja sesuai dengan kinerja yang diharapkan. Hubungan kerja yang baik antar karyawan, dan antara karyawan dengan manajemen, memberi motivasi kepada karyawan untuk mencapai kinerja yang diharapkan.

Untuk meningkatkan kinerja karyawan di Divisi Mill dan Boiler perusahaan perlu meningkatkan pemahaman karyawan terhadap SOP serta pemahaman karyawan terhadap hubungan kerja dalam perusahaan. Peningkatan pemahaman karyawan terhadap SOP serta hubungan kerja dalam perusahaan perlu dikaitkan dengan upaya untuk mencapai pol baggasse yang ditetapkan perusahaan.

\section{DAFTAR PUSTAKA}

Amilia, Winda. Perencanaan Tools Pengukuran Kinerja Perusahaan dan Karyawan Dengan Menggunakan Objective Matrix.
AGROINTEK, Vol.7, No. 1 Maret 2013, pp 29-37.

Armstrong, M., 1998. Performance Management, Clays, Ltd, St. Ives Ple, England.

Bacal, Robert, 2002. Performance Management. Jakarta : PT. SUN.

Hadiwiyono, Priscyllia Surya dan Togar W.S. Panjaitan. 2013. Perancangan Standard Operating Procedure (SOP) Departemen Human Resource (HR) di PT X. Jurnal Titra, Vol. 1, No.2, Juli 2013, pp 227-232

Mathis Robert L \& Jackson John H., 2002. Manajemen Sumber Daya Manusia. Jakarta : Salemba Empat.

Werther Jr, William B. and Keith Davis. Human Resources and Personnel Management.1996. Irwin McGraw-Hill

Listianto dan Setiaji. 2005. Pengaruh Motivasi, Kepuasan, dan Disiplin Kerja terhadap Kinerja Karyawan (Studi Kasus di Lingkungan Pegawai Kantor PDAM Kota Surakarta).

Nazir. 2009. Metode Penelitian. Ghalia, Bogor.

Prawirosentono Suyadi, 1999. Kebijakan Kinerja Karyawan. Yogyakarta : BPFE.

Wijanto, Erin Anggreani dan Eddy M. Sutanto. Pengaruh Leader Member Exchange Terhadap Kepuasan Kerja, Motivasi Kerja dan Komitmen Organisasional Karyawan Departemen Penjualan Pada PT X. AGORA Vol. 1, No. 1,2013 